\title{
KAJIAN TEORITIS UJI KERJA TURBIN ARCHIMEDES SCREW PADA HEAD RENDAH
}

\author{
Akhmad Nurdin \\ Program Magister, Jurusan Teknik Mesin \\ Universitas Sebelas Maret \\ Email: akhmadnurdin.89@gmail.com \\ Dwi Aries H \\ Jurusan Teknik Mesin \\ Universitas Sebelas Maret \\ Email: dwiarieshimawanto@gmail.com
}

\begin{abstract}
ABSTRAK
Penggunaan archimedes screw telah bergeser pemanfaatannya dari pompa menjadi sumber energi tenaga air pada head rendah sebagai turbin air. Kinerja turbin archimedes srew dipengaruhi oleh beberapa parameter antara lain tingkat rendaman turbin, sudut kemiringan turbin, pitch ratio, dan jumlah sudu. Saat rendaman turbin berada diatas titik optimal, maka akan terjadi perlambatan pada putaran, sehingga akan terjadi penurunan tekanan hidrostatik keatas. Pada kemiringan sudut yang besar, aliran air akan keluar dari jalur kanal dan mengurangi volume air pada bucket, sehingga daya yang dihasilkan tidak optimal. Apabila semakin tinggi pitch ratio volume air yang dapat ditampung pada setip kisi akan meningkat, sehingga gerakan air menggerakkan blade akan semakin kuat. Sedangkan semakin banyak jumlah sudu maka volume air pada bucket pada sudu yang semakin berkurang, sehingga gerakan air menggerakan blade melemah.
\end{abstract}

Kata kunci: archimedes screw, rendaman turbin, kemiringan turbin, pitch ratio, jumlah sudu.

\begin{abstract}
Utilization of archimedes screw has shifted from a pump to a source of hydropower at low head as a water turbine. The performance of the turbine archimedes srew affected by several parameters, including fill downstream level, turbine slope angle, pitch ratio, and number of blades. If the fill downstream level is above the optimal point, the rotation will be slowdown, so there will be a decrease in hydrostatic pressure upwards. At a large slope angle, the flow of water will come out of the canal and reduce the volume of water in the bucket, so the power produced is not optimal. When the pitch ratio at higher point the volume of water can be accommodated in the lattice strip will increase, so the water moving the blade will be stronger. While the number of blades increase, the volume of water in the bucket on the blade decreases, so the water moves the blade weakens.
\end{abstract}

Keywords: archimedes screw, fill downstream, pitch ratio, slope turbine, number of blade.

\section{PENDAHULUAN}

Pembangkit listrik tenaga air atau PLTA bekerja berdasarkan perbedaan ketinggian (head) dan debit air setiap detiknya [1]. Gambar 1 menunjukkan prinsip kerja pembangkit listrik turbin archimedes screw, dimana aliran air melewati kisi-kisi turbin sehingga menggerakkan poros turbin (energi mekanik) dan menghasilkan energi listrik melalui generator [2]. Berdasarkan jenis alirannya turbin terbagi dalam dua macam yaitu turbin impuls dan turbin reaksi. Gambar 2 a menunjukkan contoh turbin implus, dan Gambar b menunjukkan contoh turbin reaksi [1]. 


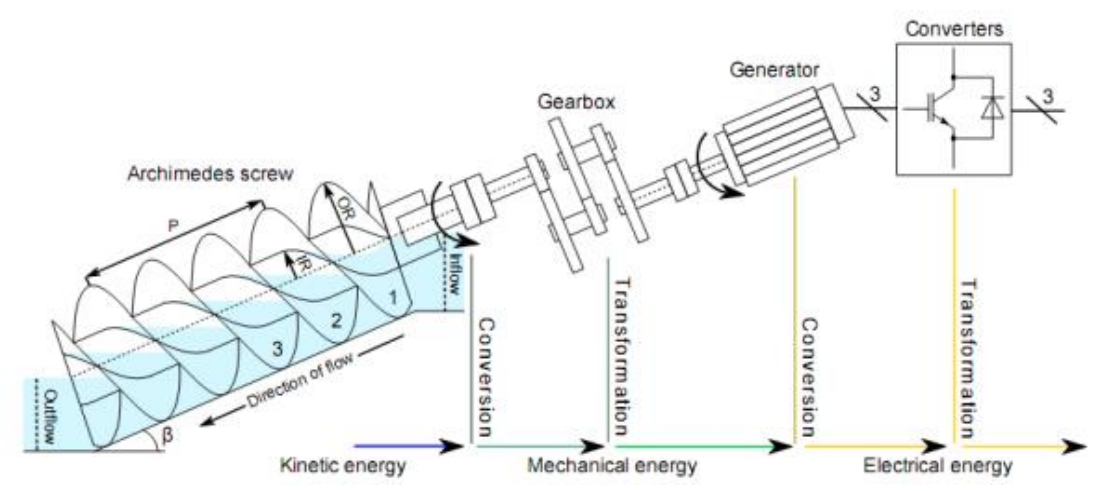

Gambar 1. Skema Pembangkit Listrik Turbin Archimedes Srew [2]
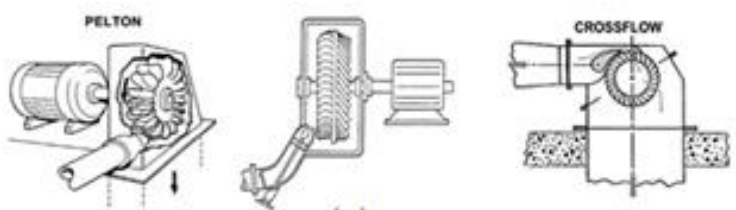

(a)
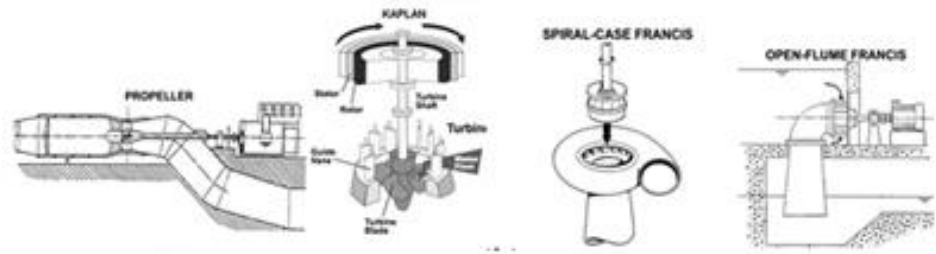

(b)

\section{Gambar 2. Macam-Macam Turbin [1]}

Selain jenis implus dan jenis reaksi, juga terdapat turbin lain, yaitu pump as turbine. Kerja dari turbin ini adalah kebalikan dari pompa, dimana output pompa sebagai saluran input, dan input pompa sebagai saluran output [3]. Salah satu jenis pump as turbine tersebut adalah archimedes screw pada awalnya merupakan peralatan kuno yang digunakan untuk memompa air yang telah ada selama ribuan tahun lalu. Pada beberapa tahun ini, archimedes screw diaplikasikan sebagai turbin untuk pembangkit listrik skala pico/micro hydro [4]. Sedangkan kerja turbin archimedes screw kebalikan dari sistem pemompaan dari archimedes screw [5].

Sejak zaman kuno teknologi archimedes srew telah ditemukan dan digunakan sebagai pompa, bentuk konstuksinya meliputi satu atau lebih sudu berbentuk ulir yang berfungsi sebagai bucket dan terhubunga dengan poros bergerak menggerakkan air ke atas. Penggunaan archimedes screw telah bergeser pemanfaatannya sebagai sumber energi tenaga air pada head rendah sebagai turbin air. Archimedes screw memiliki memiliki geometri seperti ditunjukkan gambar 4. Geometri dalam terdiri dari bagian dengan dimensi yang membentuk turbin, antara lain jari-jari dalam (jari-jari poros), jarak kisi setiap sudu (pitch), jumlah sudu. Sedangkan geometri luar terdiri dari bagian yang tidak mempengaruhi bentuk dari turbin, yaitu sudut kemiringan sudu, jari-jari luar (jari-jari blade), panjang turbin [5].

Berdasarkan gambar 4, terdapat beberapa keterangan simbol yaitu, $\mathrm{R}_{\mathrm{i}}$ : jari-jari dalam ulir $\left(0<\mathrm{R}_{\mathrm{i}}<\right.$ $\left.\mathrm{R}_{\mathrm{O}}\right), \mathrm{R}_{\mathrm{O}}$ : jari-jari luar ulir, A: jarak kisi sudu turbin $(0 \leq \mathrm{A} \leq 2 \pi \mathrm{RO} / \mathrm{K}), \mathrm{K}: \tan \beta, \beta$ : sudut kemiringan turbin, dan $\mathrm{N}$ : Jumlah sudu [6]. 


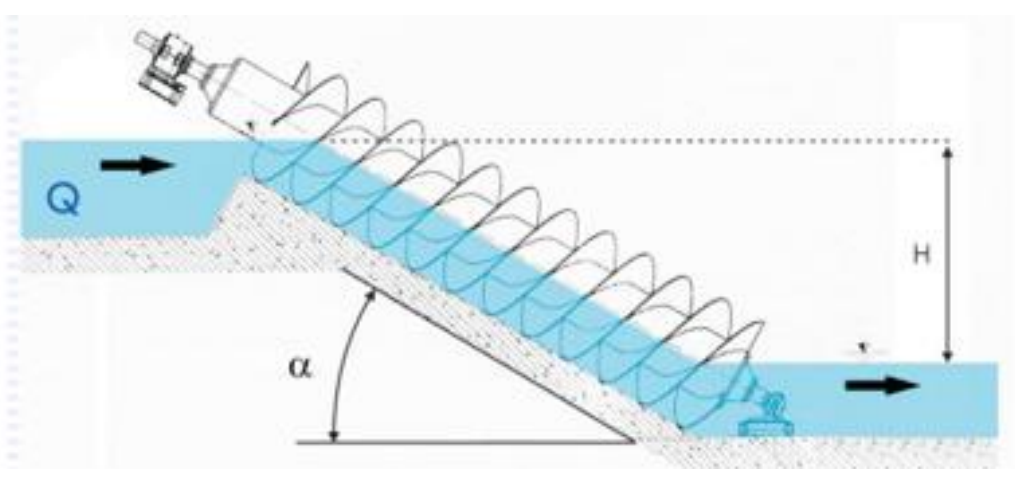

Gambar 3. Skema Turbin Archimedes Screw [5]

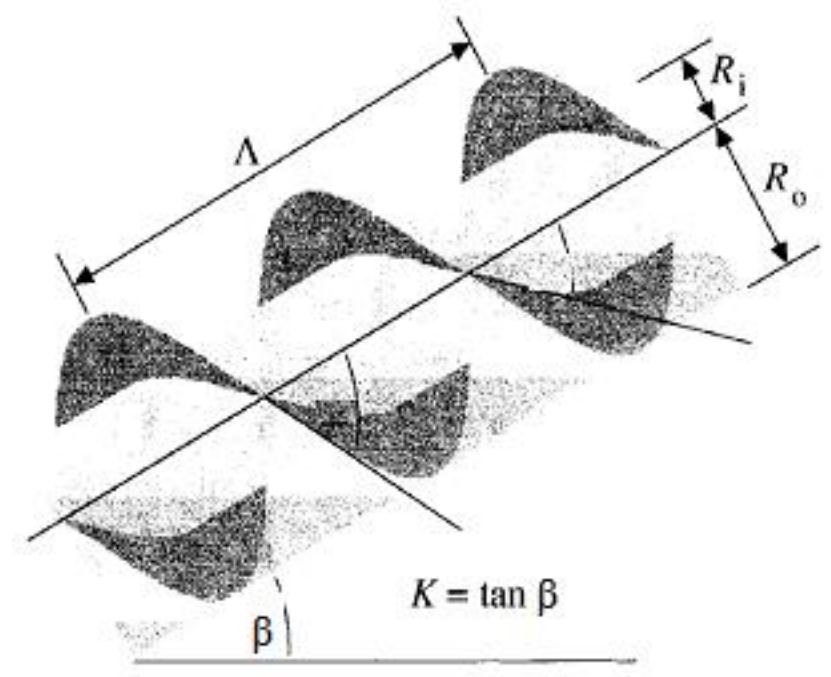

Gambar 4. Bentuk Turbin Archimedes Screw Dengan 2 Sudu [6]

Perhitungan gaya pada turbin ini diasumsikan dalam kondisi dua dimensi, turbin tetap pada kondisi miring kecepatan konstan sepanjang permukaan turbin, dan turbin tidak berputar, seperti ditunjukkan dan diilustrasikan pada gambar 5 [7].

Daya air maksimal yang terjadi adalah :

$P_{\text {avail }}=\rho g \frac{V_{b} U}{A} \Delta d$

dimana $\rho=$ densitas air $(1000 \mathrm{~kg} / \mathrm{m} 3), \mathrm{V}_{\mathrm{b}}=$ Volume bucket $(\mathrm{m} 3), \mathrm{g}=$ percepatan gravitasi $(9,81$ $\left.\mathrm{m} / \mathrm{s}^{2}\right), \mathrm{U}=$ kecepatan aliran $\operatorname{air}(\mathrm{m} / \mathrm{s}), \Delta d=$ perbedaan tinggi muka air setiap ulir. Sedangkan $d_{o}=$ tinggi muka air

Berdasarkan gambar 5 terdapat dua buah gaya yang terjadi, yaitu F1 yang arahnya ke bawah dan F2 arahnya ke atas. Sedangkan gaya gesek antara air dan permukaan material turbin diabaikan. Sehingga Berdasarkan gambar tersebut nilai masing-masing gaya yang terjadi adalah:

$F_{1}=\frac{\rho g}{2 \cos \beta}\left(d_{o}+\Delta d\right)^{2}$

$F_{2}=\frac{\rho g}{2 \cos \beta} d_{o}^{2}$ 


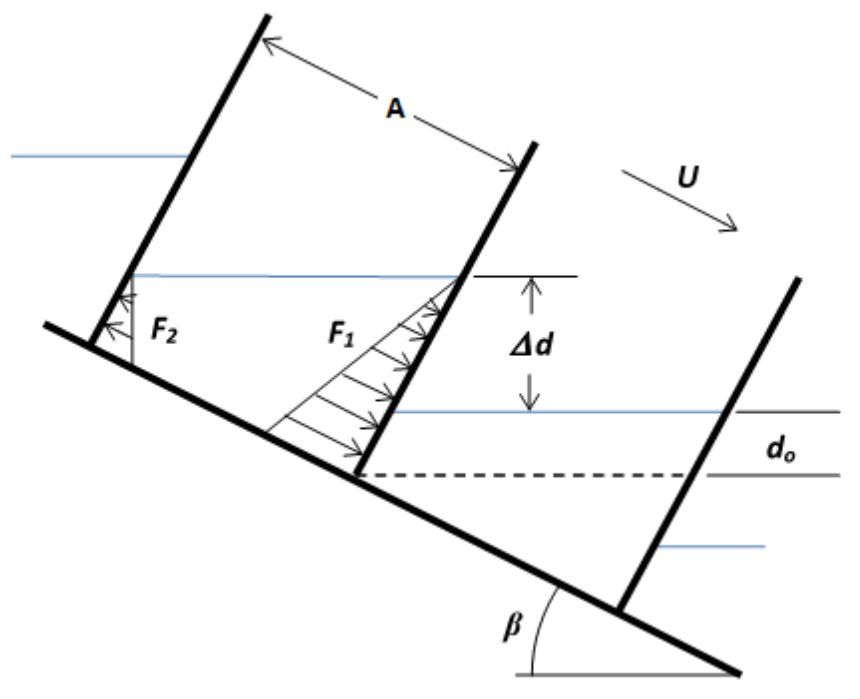

Gambar 5. Gaya Pada Turbin Archimedes Screw [7]

Dengan arah F1 dan F2 berlawanan, maka Pnet (Daya) adalah :

$P_{n e t}=\frac{\rho g}{2 \cos \beta}\left[\left(d_{o}+\Delta d\right)^{2}-d_{o}^{2}\right] U$

Berdasarkan nilai $\mathrm{P}_{\text {avail }}$ dan $\mathrm{P}_{\text {net }}$ didapat nilai efisiensi hidrolik, yaitu :

$\eta=\frac{P_{\text {nett }}}{P_{\text {avail }}}$

\section{PEMBAHASAN}

Kinerja turbin archimedes srew dipengaruhi oleh beberapa parameter antara lain tingkat rendaman turbin, sudut kemiringan turbin, pitch ratio, dan jumlah sudu.

\subsection{Pengaruh Tingkat Rendaman Turbin}

Kondisi ekstrem dilapangan (misalnya saat banjir), debit air yang melewati turbin akan naik mengakibatkan rendaman bagian bawah turbin pada level tertentu. Dalam kondisi ini, kinerja turbin akan mengalami perubahan sesuai dengan level air [8].

Rendaman level air atau fill downstream pada saluran keluar secara langsung mempengaruhi kinerja dari turbin archimedes screw. Penelitian secara eksperimental saat ini dilakukan untuk menentukan titik optimal tingkat rendaman turbin Pengujian performa turbin archimedes meliputi perbedaan outlet level (hout) pada kecepatan dan debit air yang tetap. Ilustrasi pengujian tersebut ditunjukkan pada gambar 6 . Sedangkan Untuk membandingkan hasil perbedaan output level, dapat didefinisikan sebagai Archimedes Immersion (I). Apabila $I=0$, level air terletak pada kondisi paling rendah, sebaliknya apabila $I=1$ level air terletak pada kondisi paling tinggi seperti yang ditunjukkan gamabar 7 [8].

Dellinger (2016) melakukan penelitian eksperimental pengaruh tingkat rendaman turbin pada rendaman dengan nilai $I$ 0,1 - 0,9 pada debit aliran 3L/s, putaran $80 \mathrm{RPM}$, dan sudut kemiringan $24^{\circ}$. Selain itu Songin (2017) melakukan juga melakukan penelitian eksperimental pengaruh tingkat rendaman turbin pada rendaman $0 \%$, 30\%, dan 60\% (gambar 8) dengan debit aliran $6 \mathrm{~L} / \mathrm{s}, 10 \mathrm{~L} / \mathrm{s}$, dan $14 \mathrm{~L} / \mathrm{s}$, serta sudut kemiringan $24,5^{\circ}$. Sedangkan geometri turbin dari penelitian Dellinger (2016) dan Songin (2017) masing-masing ditunjukkan pada tabel 1 . 


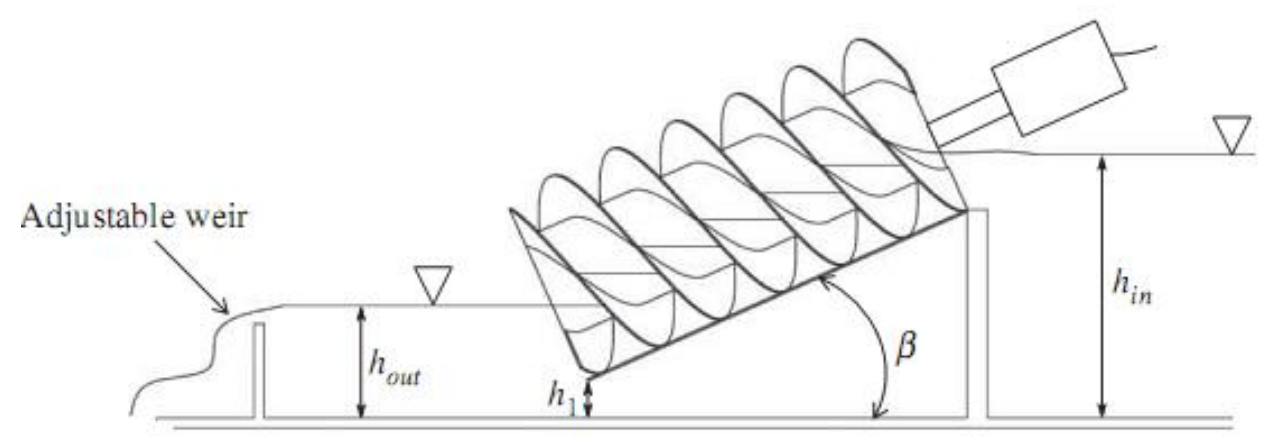

Gambar 6. Ilustrasi Uji Eksperimental [8]

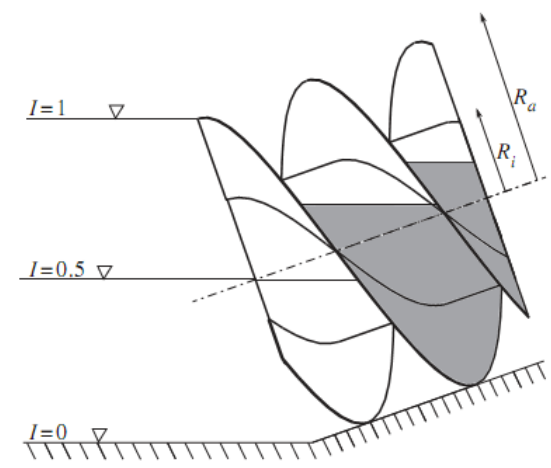

Gambar 7. Gambaran Dari Level Untuk $I=0, I=0.5$, and $I=1[8]$

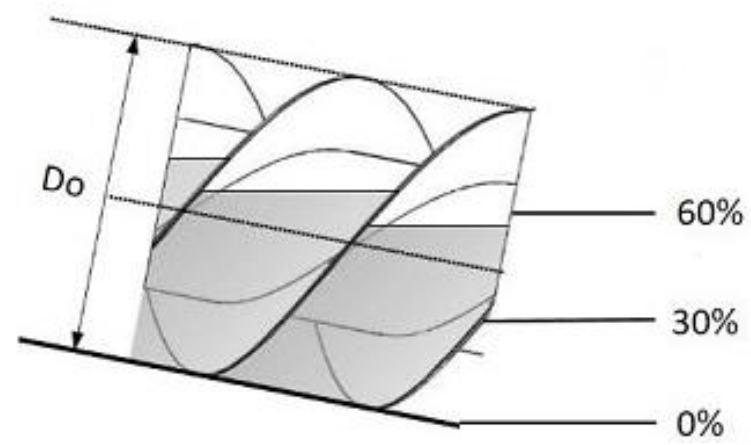

Gambar 8. Gambaran Rendaman Level Air 0\%, 30\%, dan 60\% [9]

Dellinger (2016) yang meneliti level rendaman berdasarkan $I$, dengan nilai I 0,1 sampai 0,9 dan membandingkan hasil torsi serta efisiensi. Hasil penelitian Dellinger (2016) ditunjukkan pada gambar 9, dengan nilai torsi yang dihasilkan dipengaruhi $I$ oleh rendaman, selain itu juga menunjukkan nilai optimum secara teori yaitu $I=0,596[8]$.

Tabel 1. Geometri turbin archimedes screw pada penelitian Dellinger [8] dan Songin [9]

\begin{tabular}{ccc}
\hline & Dellinger (2016) & Songin (2017) \\
\hline $\mathrm{R}_{\mathrm{o}}$ (R outer $)$ & $0,096 \mathrm{~m}$ & $0,1583 \mathrm{~m}$ \\
$\mathrm{R}_{\mathrm{i}}($ R inner $)$ & $0.052 \mathrm{~m}$ & $0,0635 \mathrm{~m}$ \\
$\mathrm{~S}$ (Pitch) & $0,192 \mathrm{~m}$ & $0,3175 \mathrm{~m}$ \\
$\mathrm{~L}$ (Length) & $0,4 \mathrm{~m}$ & $1,2192 \mathrm{~m}$ \\
$\mathrm{~N}$ (Jumlah Sudu) & 3 & 4 \\
\hline
\end{tabular}


Gambar 9 juga menunjukkan nilai torsi yang terjadi pada turbin archimedes screw menurun saat nilai rendaman $I$ naik. Hal ini disebabkan rendaman air memberikan tekanan balik pada sudu yang terendam air. Sedangkan efisiensi meningkat seiring nilai $I$ naik sampai 0,64 , setelah itu efisiensi menurun. Turbin akan mencapai titik optimal apabila rendaman air sesuai dengan ketinggian air pada bucket terakhir (paling bawah). Saat rendaman air berada diatas daerah tersebut air akan berusaha kembali masuk ke bucket. Fenomena ini mengakibatkan perlambatan pada putaran dan menurunkan performa turbin. Jika outlet level berada dibawah titik optimalnya, maka nilai torsi pada turbin akan meningkat, hal ini disebabkan adanya penurunan tekanan hidrostatik keatas atau tekanan F2 (persamaan 3) pada sudu terakhir [8].

Songin (2017) meneliti dengan hasil daya, dan efisiensi pada masing-masing rendaman dan debit dengan putaran yang dijaga pada $20 \mathrm{rpm}, 30 \mathrm{rpm}, 40 \mathrm{rpm}, 50 \mathrm{rpm}, 60 \mathrm{rpm}$, dan $80 \mathrm{rpm}$. Hasil penelitian ini ditunjukkan pada gambar 10 dan gambar 11. Gambar 10 menunjukkan pengaruh variasi tingkat rendaman dan debit terhadap daya yang dihasilkan turbin archimedes screw, dimana level rendaman air secara eksperimental sangat berpengaruh terhadap daya yang dihasilkan. Pada rendaman $0 \%$ dan $30 \%$ dengan bervariasi debit menunjukkan tren yang sama dengan nilai daya yang tidak berbeda jauh, namun pada rendaman 0\% memiliki nilai sedikit lebih dibandingkan 30\%. Saat rendaman mencapai $60 \%$ terjadi penurunan nilai daya [9].

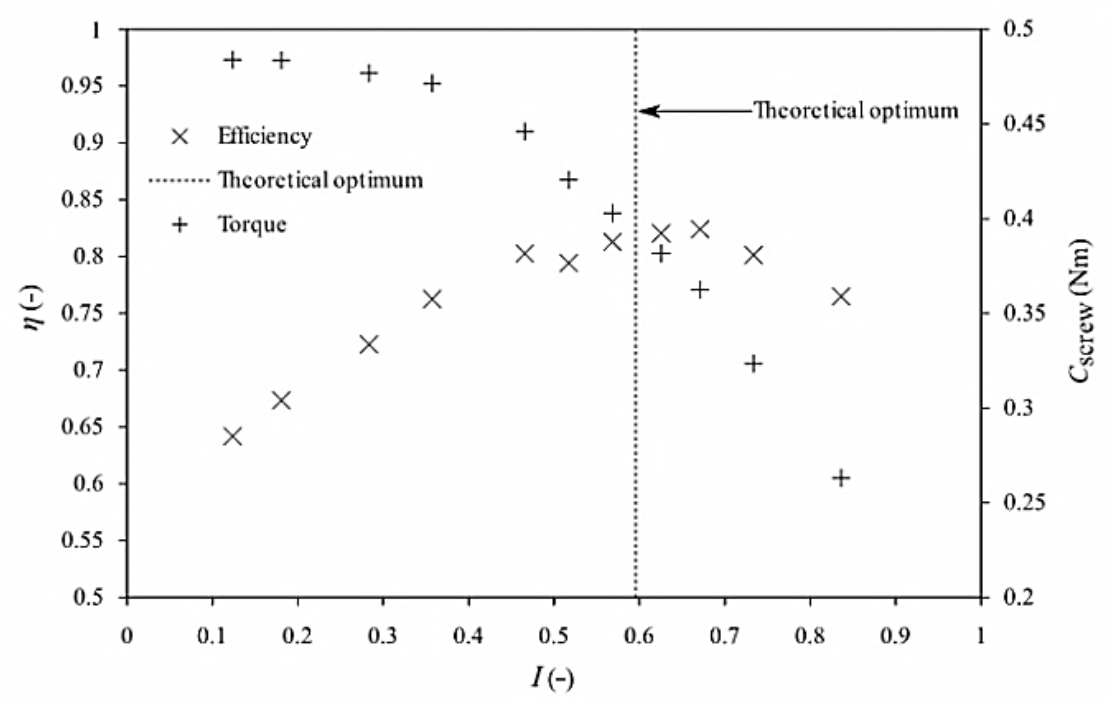

Gambar 9. Pengaruh I Terhadap Torsi Dan Efisiensi [8]

Sedangkan ditinjau dari putaran poros yang meningkat, terdapat perbedaan antara daya dari 0\% dan $30 \%$ dibandingkan dengan $60 \%$. Pada rendaman $60 \%$ terdapat tekanan putaran balik pada saluran keluar, sehingga torsi akan menurun karena gaya hambatan dan mempengaruhi daya poros yang dihasilkan. Selain itu pada putaran diatas 50 RPM air pada keluar bucket turbin (berpercikan), namun hal tersebut tidak terjadi pada putaran rendah. Gambar 11 Menunjukkan pengaruh variasi tingkat rendaman dan debit terhadap efisiensi pada turbin archimedes screw. Berbeda dengan daya, nilai tertinggi efisiensi dipengaruhi oleh perubahan debit aliran. Nilai efisiensi tertinggi didapat pada rendaman $0 \%$ dengan debit $6 \mathrm{~L} / \mathrm{s}$, dan semakin menurun seiring bertambahnya putaran dan debit [9].

Secara keseluruhan nilai efisiensi semakin meningkat dengan bertambahnya nilai hout hal ini disebabkan pada teori (persamaan no 4) dimana semakin meningkatnya level ketinggian air pada bucket $\left(d_{0}\right)$ head semakin pendek dan daya akan menurun. Pada kondisi lainnya, yaitu pada aliran debit 6L/s semakin cepat putaran turbin, maka daya akan semakin menurun yang disebabkan head semakin pendek, sehingga akan mengurangi nilai efisiensi pada kasus rendaman diatas 30\%. Kecepatan putar archimedes screw dipengaruhi air oleh jumlah volume pada bucket, dimana putaran tergantung pada besarnya gaya hidrostatik yang terjadi pada sudu archimedes screw dan efisiensi meningkat seiring dengan semakin penuhnya volume air di dalam bucket [9]. 


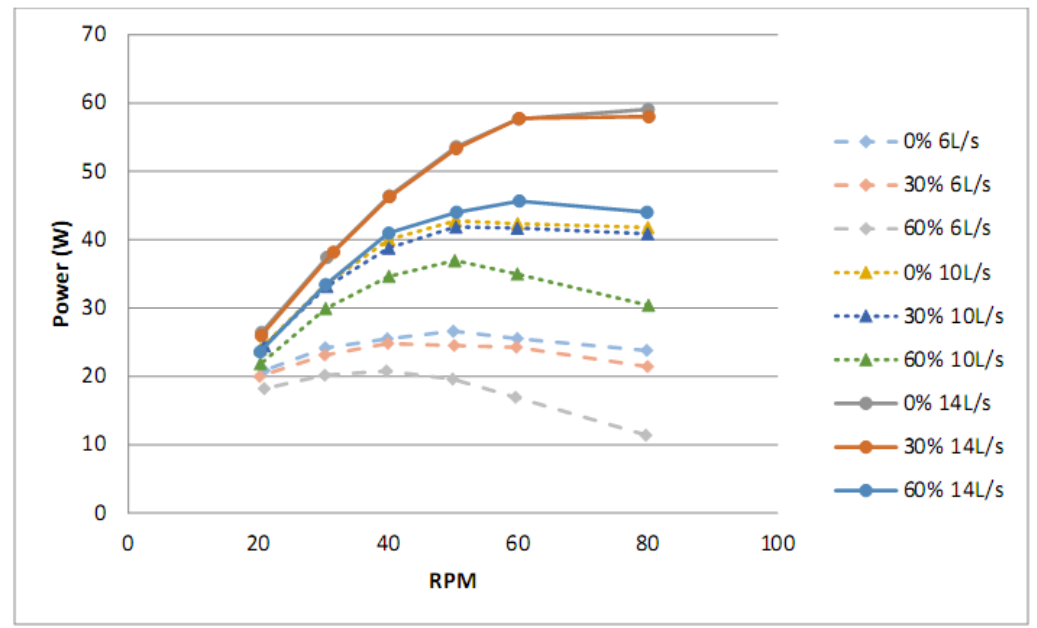

Gambar 10. Pengaruh Level Rendaman Air Terhadap Daya (Watt) [9]

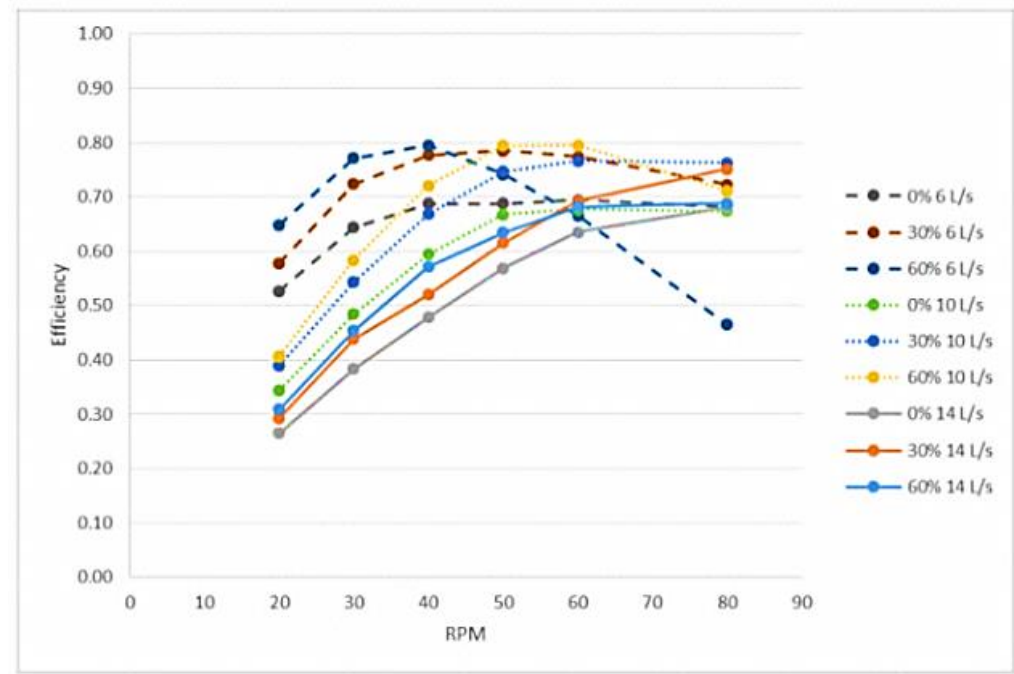

Gambar 11. Pengaruh Level Rendaman Air Terhadap Efisiensi [9]

\subsection{Pengaruh Kemiringan Sudu}

Salah satu geometri luar yang mempengaruhi kinerja turbin archimedes screw yaitu kemiringan sudu [10]. Yulistianto (2012) melakukan uji eksperimental pengaruh kemiringan sudu terhadap kinerja turbin archimedes srew dengan geometri dimensi pitch $1,6 \mathrm{R}_{0}, 2$ buah sudu, dan dimensi lainnya seperti ditunjukkan gambar 12. Sedangkan variasi kemiringan sudu yang digunakan 25, 30, 35, 40, 45, dan 50 derajat dengan debit mulai dari 3,6 sampai 6,8 liter per detik [11]. Selain itu Saroinsong (2016) juga melakukan uji eksperimental pengaruh kemiringan sudu terhadap kinerja turbin archimedes srew dengan geometri Ro 0,055 meter, Ri 0.03 meter3, buah sudu, dan model turbin ditunjukkan gambar 13 . Sedangkan variasi kemiringan sudu yang digunakan adalah 25, 35, dan 45 derajat dengan laju aliran air $0,5 \mathrm{~m} / \mathrm{s}[12]$.

Hasil uji eksperimentalYulistianto (2012) ditunjukkan pada gambar 14 dan gamber 15. Gambar 14 menunjukkan daya turbin yang dihasilkan dengan beberapa variasi kemiringan sudu, dimana semakin besar kemiringan sudu dari 25 sampai 40 derajat semakin meningkat daya turbin, serta meningkatnya daya turbin akan lebih signifikan dengan semakin meningkatnya debit. Namun semakin bertambah nilai kemiringan 45 dan 50 derajat daya turbin akan menurun pada semua nilai debit. Pada saat kemiringan sudut kecil (25 sampai 45 derajat) aliran debit air menggerakan blade dengan gaya yang sedikit (ringan). Sedangkan pada sudut lebih besar (45 dan 50 derajat) aliran air akan mulai keluar dari jalur kanal, sehingga mengurangi volume air pada bucket yang dapat terkonversi menjadi daya turbin. [11]. 

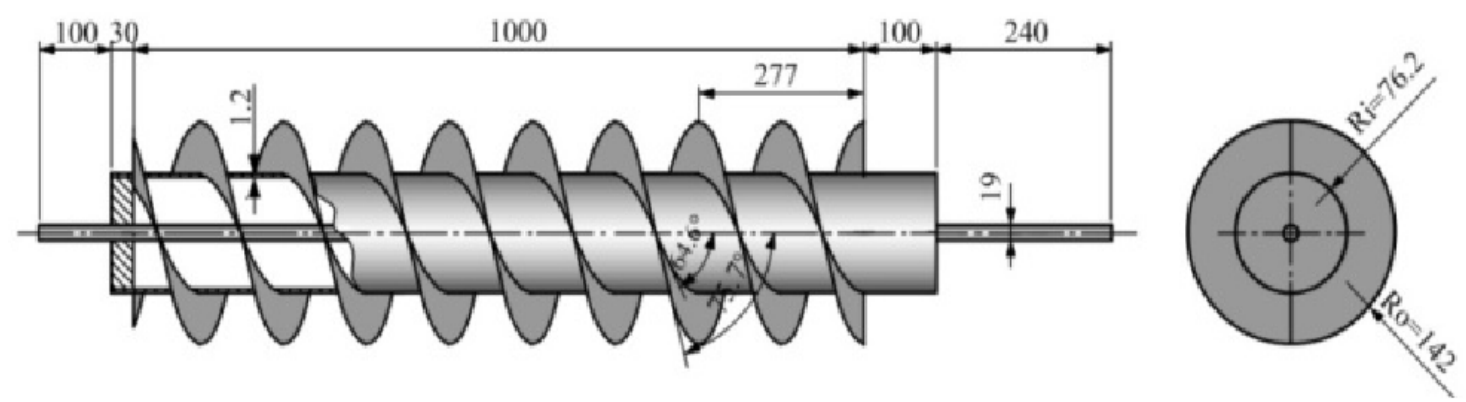

Gambar 12. Design Turbin Uji Eksperimental [11]

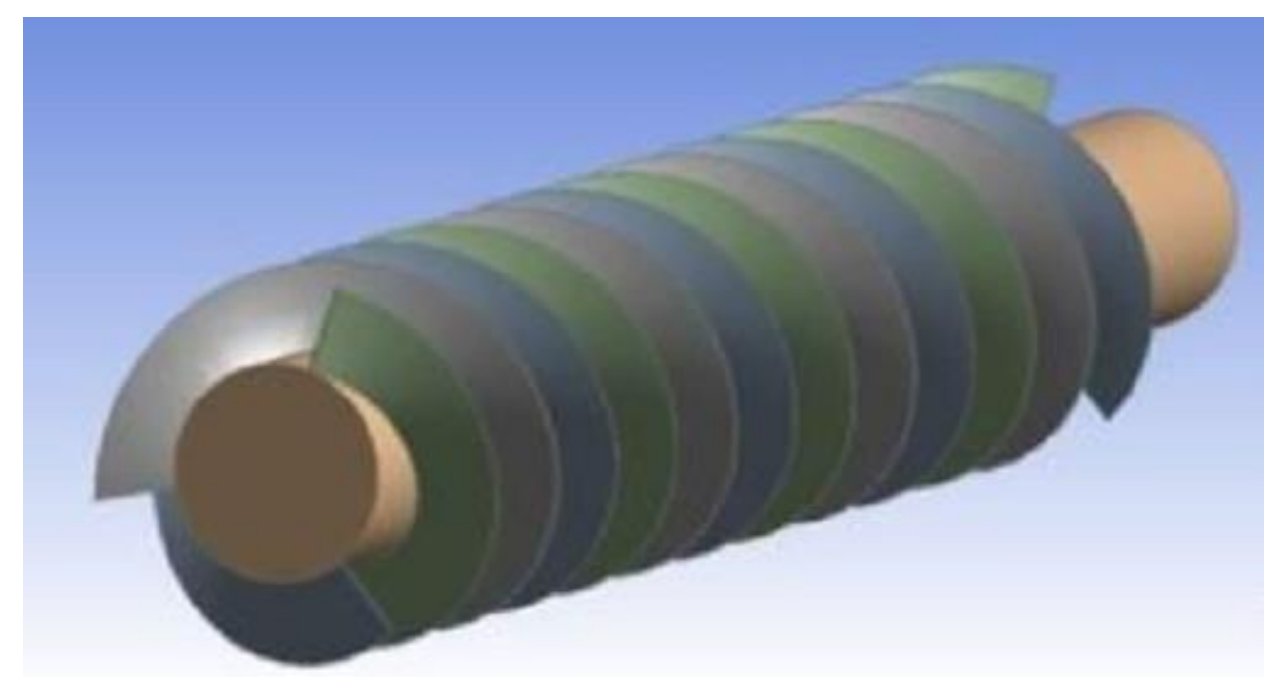

Gambar 13. Model Turbin 3 Sudu Tanpa Dimensi [12]

Gambar 15 menunjukkan semakin kecil debit air, maka efisiensi turbin akan menurun dengan meningkatnya kemiringan sudu. Sebaliknya, semakin besar nilai debit air, maka efisiensi akan naik pada kemiringan sudu dari 25 sampai 35 atau 40 derajat, selanjutnya akan menurun. Pada turbin dengan kemiringan sudu 50 derajat, nilai efisiensi lebih rendah dibandingkan kemiringan sudu lainnya. Hal ini disebabkan saat aliran air melewati turbin pada bagian tepi saluran, air akan keluar dari blade sehingga akan mengurangi volume air pada bucket yang dapat terkonversi menjadi daya turbin [11].

Berdasarkan hasil daya dan efisiensi dari penelitian Yulistianto (2012) tersebut didapat nilai optimal pada kemiringan susu antara 35 dan 40 derajat, terutama saat debit air yang lebih besar [11]. Hasil uji eksperimental Saroinsong (2016) ditunjukkan pada gambar 16 dan gamber 17. Gambar 16 semakin besar nilai kemiringan sudu maka daya turbin yang dihasilkan semakin besar. Hal ini menunjukkan pada penelitian ini semakin besar besar nilai kemiringan sudu maka putaran turbin semakin cepat, sehingga daya turbin yang dihasilkan semakin besar [12]. 


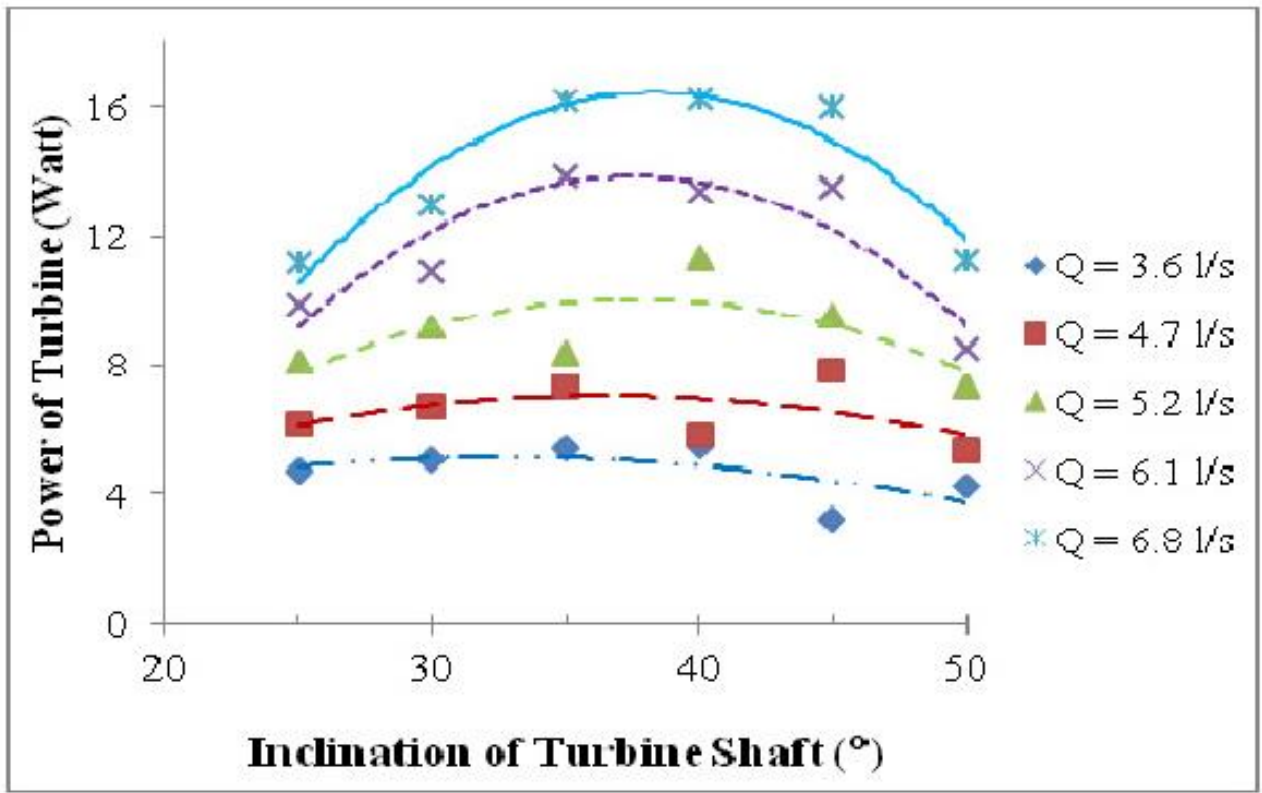

Gambar 14. Pengaruh Sudut Kemiringan Sudu Turbin Terhadap Daya Turbin [11]

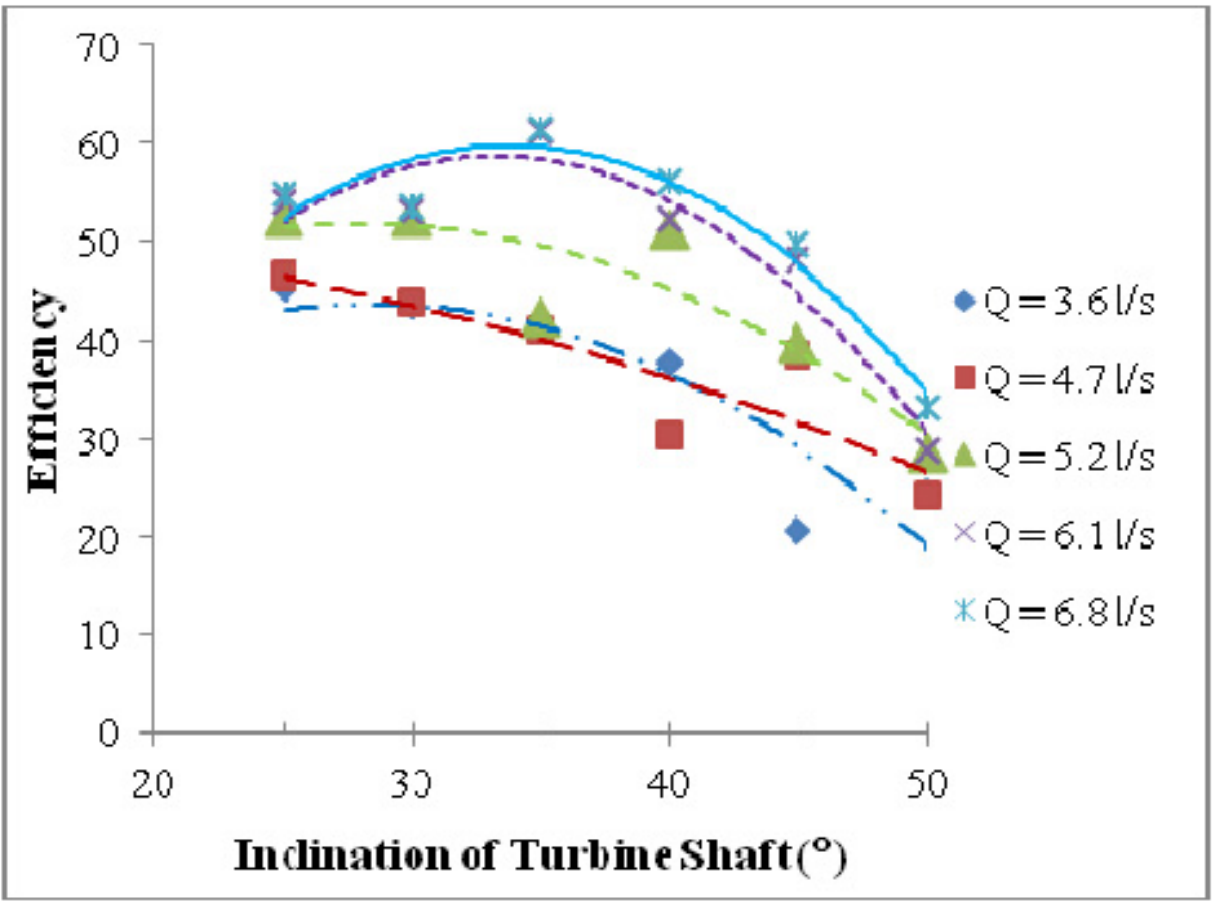

Gambar 15. Pengaruh Sudut Kemiringan Sudu Turbin Terhadap Efisiensi Turbin [11]

Gambar 17 menunjukkan efisiensi tertinggi pada putaran $50 \mathrm{rpm}$ pada masing-masing kemiringan sudu, terutama pada kemiringan sudu 25 derajat yang menunjukkan nilai terbesar mencapai $89 \%$. Nilai efiseiensi yang sama ditunjukkan pada kemiringan sudu 25, 35, dan 35 derajat pada masing-masing rotasi $250 \mathrm{rpm}, 300 \mathrm{rpm}$, dan $350 \mathrm{rpm}$ [12]. Berdasarkan hasil daya dan efisiensi dari penelitian Saroinsong (2016) tersebut didapat nilai optimal pada kemiringan sudu 25 derajat pada putaran turbin $50 \mathrm{rpm}$ [12]. 


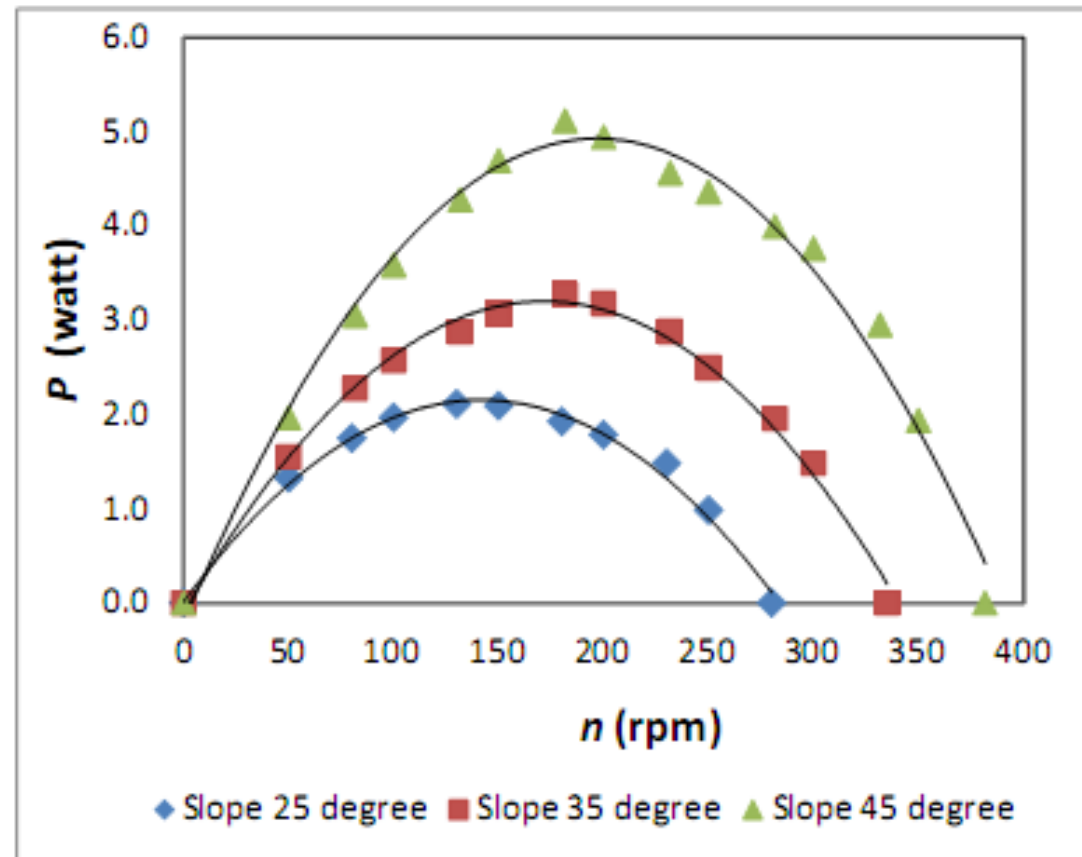

Gambar 16. Hubungan Antara Putaran Turbin Dan Daya Turbin Dengan Variasi Kemiringan Sudu [12]

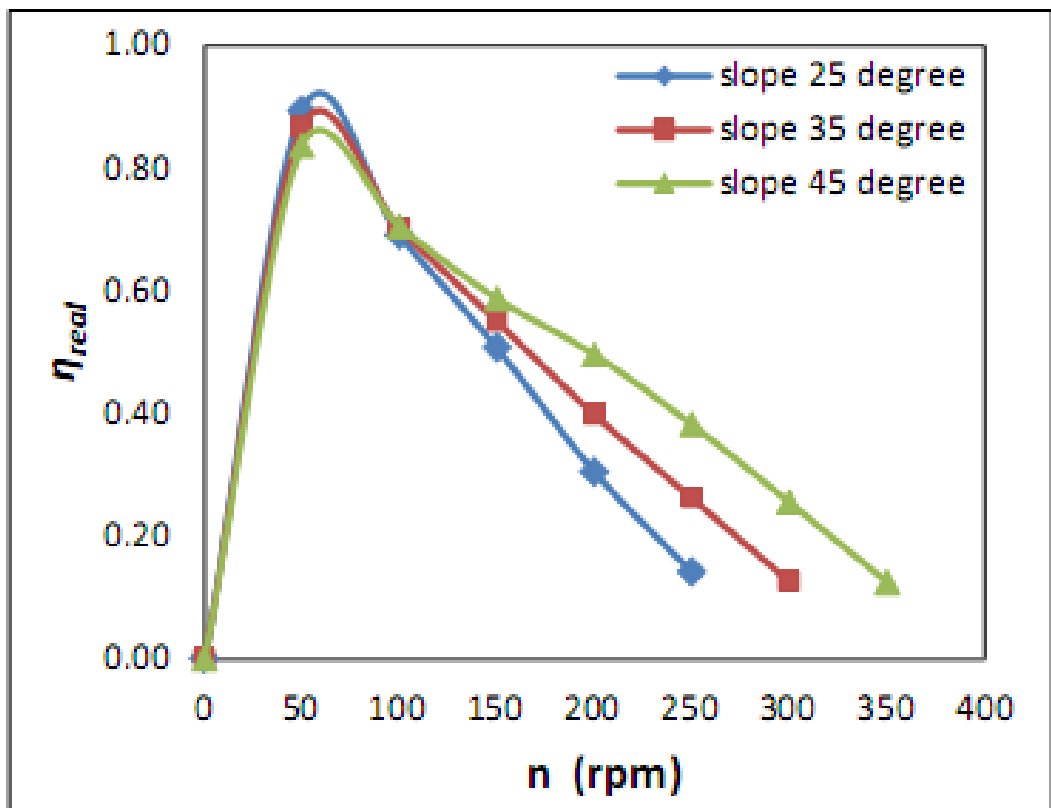

\section{Gambar 17. Hubungan Antara Putaran Turbin Dan Efisiensi Turbin Dengan Variasi Kemiringan} Sudu [12]

\subsection{Pengaruh Pitch Ratio}

Pitch ratio $(\mathrm{Pr})$ merupakan perbandingan antara dimensi pitch dengan diameter luar turbin. Dengan panjang turbin yang sama, nilai pitch ratio akan mempengaruhi ukuran dan jumlah kisi. Waters (2015) meneliti pengaruh nilai pitch ratio terhadap torsi yang dihasilkan pada beberapa beda ketinggian (head) menggunakan simulasi computional fluid dynamic (CFD). Variasi pitch ratio yang digunakan yaitu 0.5, 1.0, dan 2.0 dengan dua geometri diantaranya ditunjukkan pada gambar 18 (Pr:2,0) dan gambar 19 (Pr:0,5) [13]. 
Hasil simulasi $C F D$ ditunjukkan gambar 20, nilai torsi terbesar terjadi pada nilai pitch ratio 2,0 terutama pada nilai head yang tertinggi. Semakin tinggi nilai pitch ratio, maka nilai torsi yang dihasilkan semakin meningkat, hal ini disebabkan pada pitch ratio yang lebih besar (dengan panjang yang sama) maka jumlah kisi akan semakin sedikit. Semakin sedikit jumlah kisi, volume air yang dapat ditampung pada setip kisi akan meningkat, sehingga gerakan air menggerakkan blade akan semakin kuat, dan torsi yang dihasilkan semakin meningkat [13].

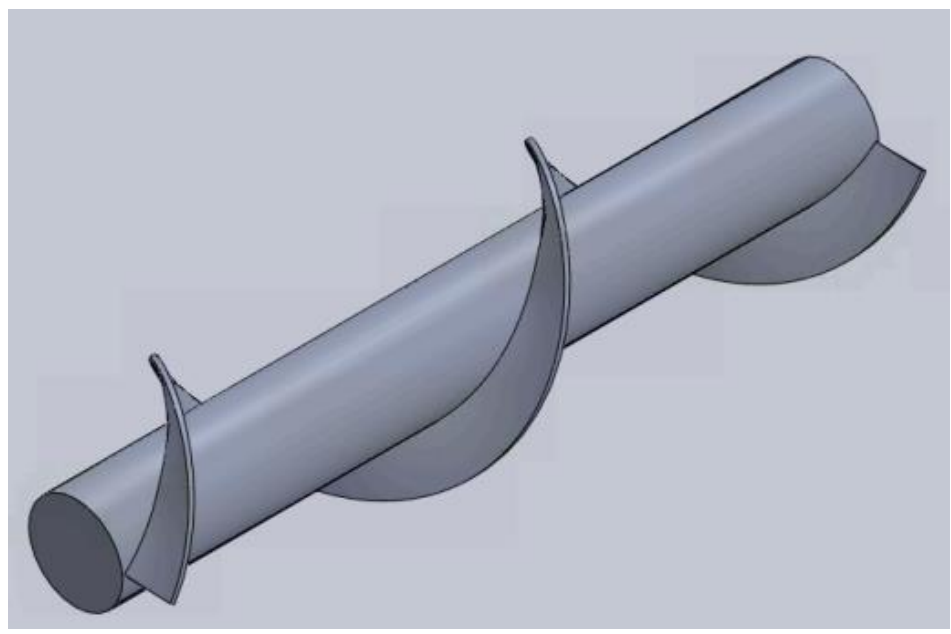

Gambar 18. Geometri Turbin Pada Pitch Ratio 2,0 [13]

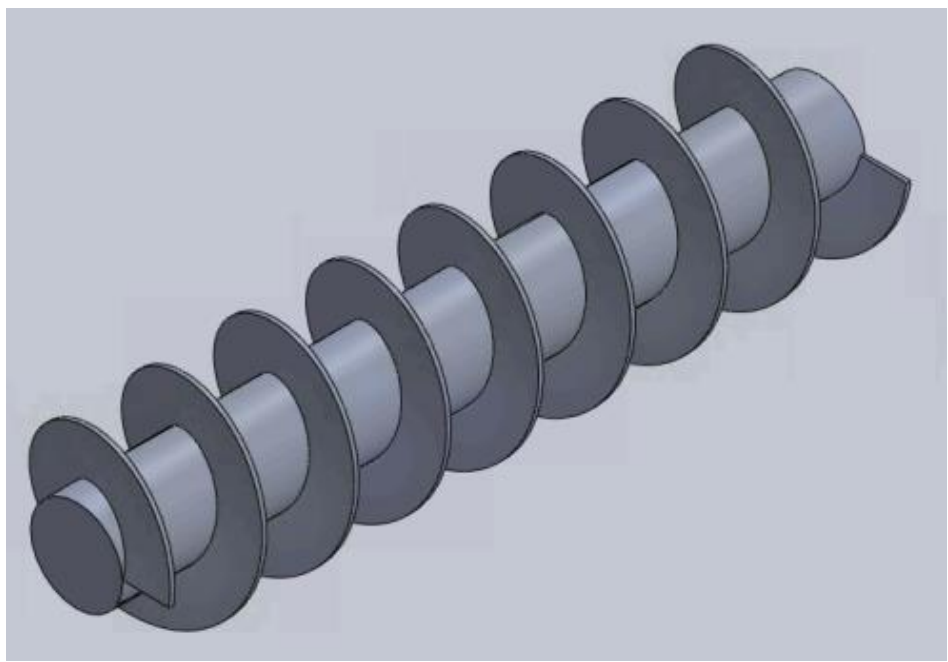

Gambar 19. Geometri Turbin Pada Pitch Ratio 0,5 [13]

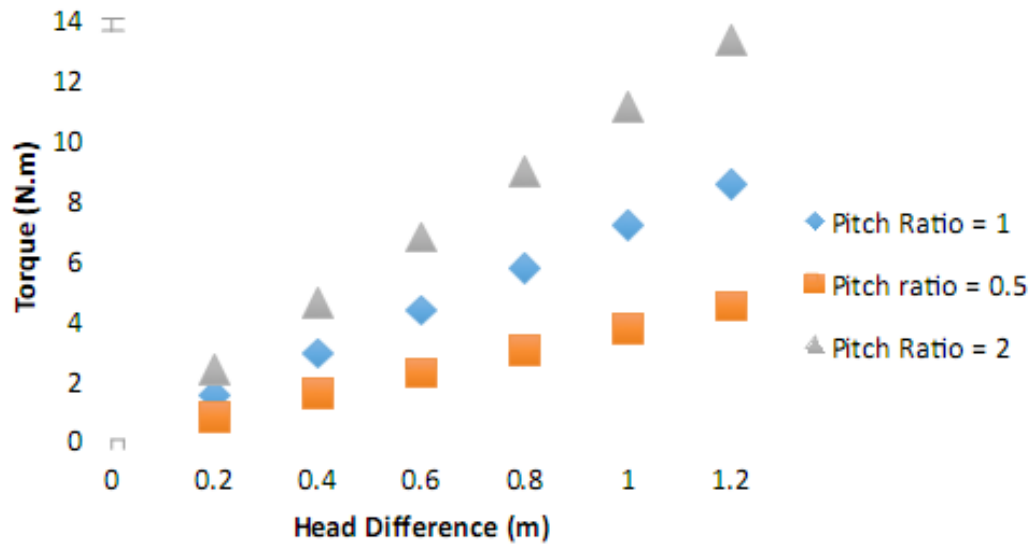

Gambar 20. Hubungan Antara Head Turbin Dan Torsi Turbin Dengan Variasi Pitch Ratio [13] 


\subsection{Pengaruh Jumlah Sudu}

Waters (2015) meneliti pengaruh jumlah sudu terhadap torsi yang dihasilkan pada beberapa beda ketinggian (head) menggunakan simulasi Computional Fluid Dynamic (CFD). Variasi jumah sudu yang digunakan yaitu 1, 3, dan 5 dengan dua geometri diantaranya ditunjukkan pada gambar 18 (3 sudu) dan gambar 19 (5 sudu) [13].

Hasil simulasi $C F D$ ditunjukkan gambar 21, nilai torsi terbesar terjadi pada jumlah sudu 1 buah terutama pada nilai head yang tertinggi. Hal ini berkebalikan dengan pernyataan Rosses (2000) yang menyatakan semakin banyak jumlah sudu pada pompa archimedes screw, maka performa turbin akan meningkat, hal ini disebabkan pada penelitian tersebut tidak diperhitungkan faktor ketebalan sudu yang digunakan dan kerugian debit air yang keluar dari saluran [13].

Menurunnya nilai torsi pada jumlah sudu yang semakin meningkat (dengan panjang poros sama) volume bucket pada sudu yang semakin berkurang, sehingga performa turbin akan semakin menurun seiring bertambahnya sudu [13].

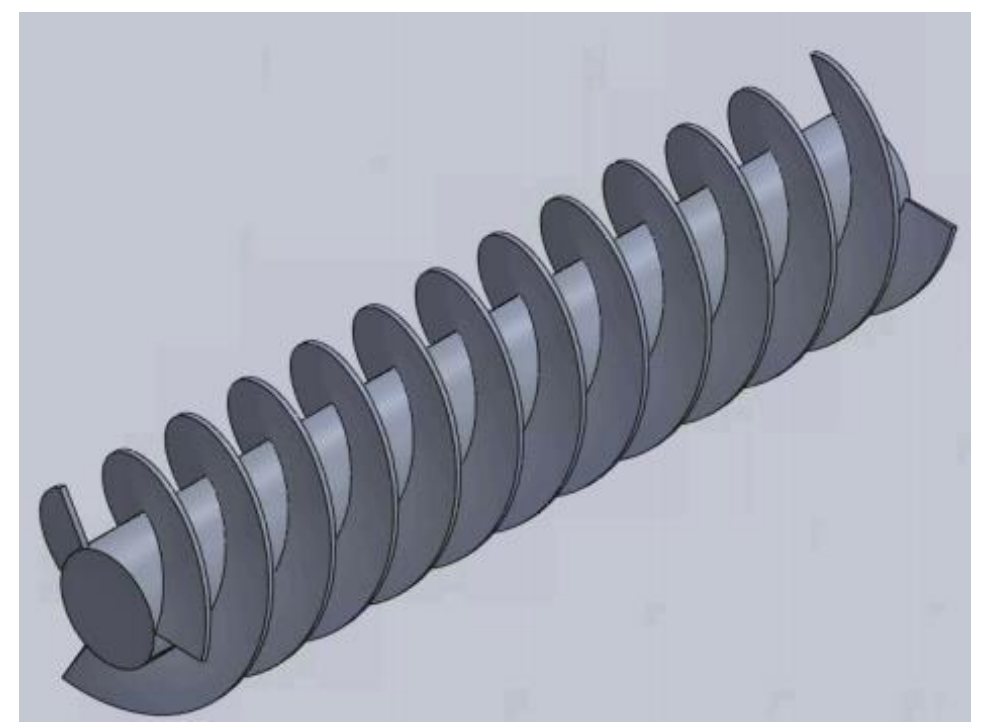

Gambar 21. Geometri Turbin Dengan 3 Buah Sudu [13]

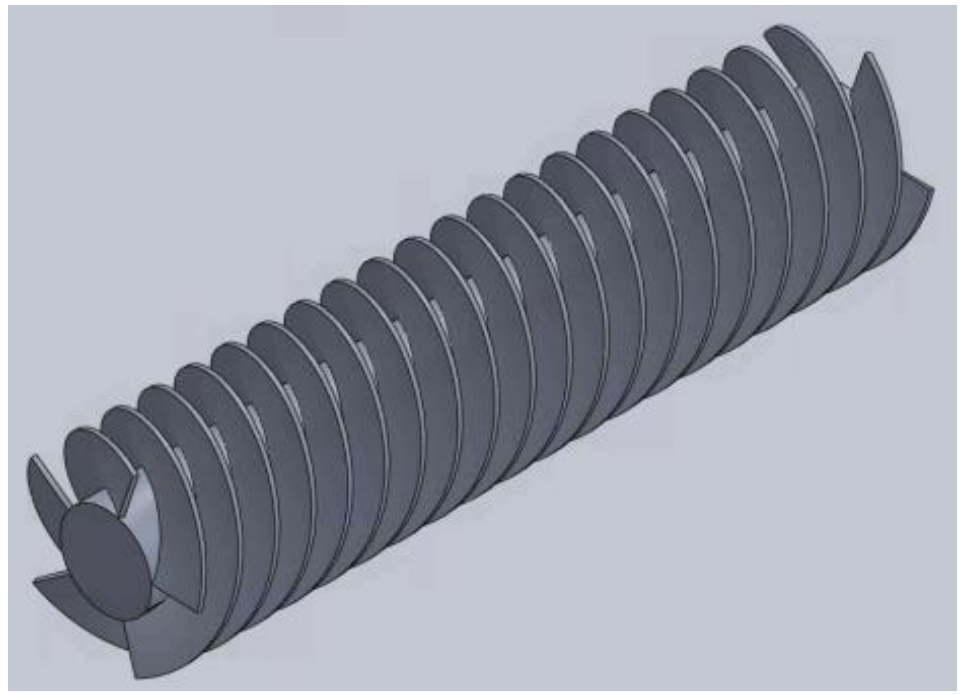

Gambar 22. Geometri Turbin Dengan 5 Buah Sudu [13] 


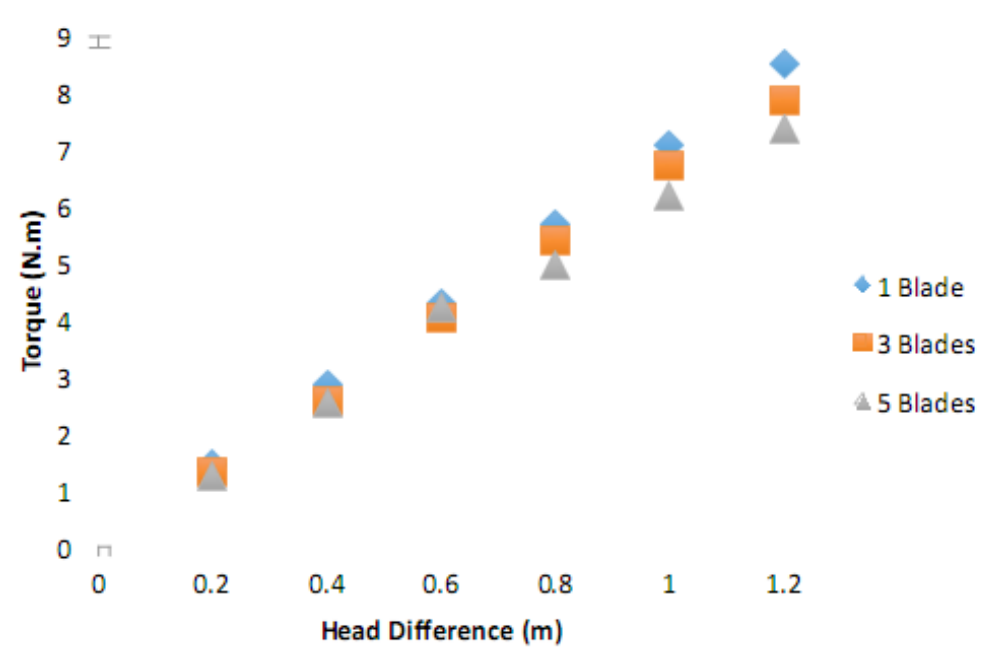

Gambar 20. Hubungan Antara Head Turbin Dan Torsi Turbin Dengan Variasi Jumlah Sudu [13]

\section{KESIMPULAN}

Selain berfungsi sebagai pompa archimedes screw dapat digunakan sebagai turbin. Berdasrkan kajian-kajian teoritis yang telah dipelajari, dapat disimpulkan beberapa poin sebagai berikut :

1. Kinerja turbin archimedes srew dipengaruhi oleh beberapa parameter antara tingkat rendaman turbin, sudut kemiringan turbin, pitch ratio, dan jumlah sudu.

2. Pada parameter tingkat rendaman turbin, apabila rendaman berada diatas optimal air akan berusaha kembali masuk ke bucket, hal ini mengakibatkan perlambatan pada putaran dan menurunkan performa turbin sehingga akan terjadi penurunan tekanan hidrostatik keatas.

3. Pada parameter kemiringan sudut yang besar, daya dan efisiensi yang dihasilkan akan menurun, hal ini disebabkan aliran air akan mulai keluar dari jalur kanal, sehingga mengurangi volume air pada bucket yang dapat terkonversi menjadi daya turbin.

4. Pada paremeter pitch ratio dengan simulasi CFD, semakin tinggi nilai pitch ratio, maka nilai torsi yang dihasilkan semakin meningkat, hal ini disebabkan pada pitch ratio yang lebih besar maka jumlah kisi akan semakin sedikit. Semakin sedikit jumlah kisi, volume air yang dapat ditampung pada setip kisi akan meningkat, sehingga gerakan air menggerakkan blade akan semakin kuat.

5. Pada parameter jumlah sudu dengan simulasi CFD, semakin banyak jumlahnya maka torsi yang dihasilkan akan menurun, hal ini disebabkan volume bucket pada sudu yang semakin berkurang, sehingga performa turbin akan semakin menurun seiring bertambahnya sudu.

\section{DAFTAR PUSTAKA}

[1] A. Nurdin, "Optimalisasi Transmisi PLTA - Pico Hydro sebagai Penunjang Konversi Energi Mekanik Menjadi Listrik," Universitas Sebelas Maret, Surakarta, 2016.

[2] J. Rohmer, D. Knittel, G. Sturtzer, D. Flieller, and J. Renaud, "Modeling and experimental results of an Archimedes screw turbine," Renewable Energy, vol. 94, pp. 136-146, 2016.

[3] M. Stefanizzi and B. Fortunato, "Experimental investigation and performance prediction modeling of The investigation 15th International and Experimental performance prediction modeling of a single stage centrifugal pump operating as turbine a single stage cent," Energy Procedia, vol. 126, pp. 589-596, 2017.

[4] N. Dellinger and M. Dufresne, "Computational fluid dynamics modeling for the design of Archimedes Screw Generator,” vol. 118, 2018.

[5] H. B. Harja, H. Abdurrahim, S. Yoewono, and H. Riyanto, "Penentuan Dimensi Sudu dan Sudut Kemiringan Turbin Pada Turbin Ulir Archimedes," vol. 36, no. 1, 2014.

[6] C. Rorres, "The Turn of The Screw: Optimal Desibn of an Archimedes Screw," no. January, pp. 72 80, 2000.

[7] W. D. Lubitz, M. Lyons, and S. Simmons, "Performance Model of Archimedes Screw Hydro Turbines with Variable Fill Level," Journal of Hydraulic Engineering, vol. 140, no. 10, p. $04014050,2014$. 
[8] G. Dellinger, A. Terfous, and P. Garambois, "Experimental investigation and performance analysis of Archimedes screw generator," vol. 1686, no. March, 2016.

[9] K. Songin, "Experimental Analysis of Archimedes Screw Turbines," 2017.

[10] A. D. Nugroho and D. A. Himawanto, "Kajian Teoritik Pengaruh Geometri Dan Sudut Kemiringan Terhadap Kinerja Turbin Archimedes Screw," Seminar Nasional Teknologi Informasi dan Kedirgantaraan (SENATIK), vol. III, pp. 2337-3881, 2017.

[11] B. Yulistiyanto, H. Yul, and Lisdiyanti, "Pengaruh Debit Aliran dan Kemiringan Poros Turbin Ulir Pada Pembangkit Listrik Tenaga Mikro-hidro,” Dinamika Teknik Sipil vol. 12, no. 1, pp. 1-5, 2012.

[12] T. Saroinsong, R. Soenoko, S. Wahyudi, and M. N. Sasongko, "Performance of three-bladed Archimedes screw turbine," ARPN Journal of Engineering and Applied Sciences, vol. 11, no. 15, pp. 9491-9495, 2016.

[13] S. R. Waters, "Analysing the performance of the Archimedes Screw Turbine within tidal range technologies," no. November, pp. 1-171, 2015. 